\title{
PLUM OIL CAKE PROTEIN ISOLATE: A POTENTIAL SOURCE OF BIOACTIVE PEPTIDES
}

\author{
Jelena C. Čakarević ${ }^{1}$, Senka S. Vidović ${ }^{1}$, Jelena Z. Vladić1, Stela D. Jokić ${ }^{2}$ Nika S. Pavlović ${ }^{3}$, Ljiljana \\ M. Popović* ${ }^{1}$ \\ ${ }^{1}$ University of Novi Sad, Faculty of Technology, 21000 Novi Sad, Bulevar cara Lazara 1, Serbia \\ ${ }^{2}$ J.J. Strossmayer University of Osijek, Faculty of Food Technology, 31000 Osijek, Trg Svetog Trojstva \\ 3, Croatia \\ ${ }^{3}$ J.J. Strossmayer University of Osijek, Faculty of Medicine, 31000 Osijek, Cara Hadrijana 10E, Croatia
}

\author{
*Corresponding author: \\ Phone: +381214853659 \\ Fax: +38121450413 \\ E-mail address: Ijiljana04@tf.uns.ac.rs
}

\begin{abstract}
In this study some functional properties and the in vitro digestibility of protein isolates from plum oil cakes, obtained by supercritical fluid extraction and cold pressing, as a control, were described and compared. Amygdalin contents in the protein isolates were at amounts considerably lower than regulatory. Solubility profiles of both protein isolates were typical for this type of plant proteins. Proteins showed good digestibility, which was assessed by gastrointestinal proteases (pepsin and pancreatin). SDS-PAGE analysis was used for characterisation of protein digests which showed that the protein isolates were completely digested. In vitro antioxidant capacity by three complementary methods and enzyme inhibitory effects towards Angiotensin-l Converting Enzyme (ACE) related to the onset of hypertension were determined. All obtained protein hydrolysates acted as DPPH and ABTS scavengers, as reducing agents and also as ACE enzyme inhibitor. Hence, the protein isolates obtained from plum kernel cake showed to be a potential source of natural products for food applications, with good digestibility and beneficial bioactive properties.
\end{abstract}

Key words: plum kernel protein, supercritical $\mathrm{CO}_{2}$ extraction, in vitro digestion, ACE inhibition, antioxidant activity

\section{INTRODUCTION}

The plum (Prunus domestica) is a member of Prunus family, along with apricot, cherry and peach, and one of the most widespread stone fruits crops around the world. In Serbia, plums represent the most dominant fruit crops which is consumed fresh, dried or used for preparation of different value-added products. The processing of plums into the foodstuffs produces tonnes of by-products in the form of fruit pits which have great potential as an unconventional valuable source of oil, rich in bioactive compounds such as phyto- sterols, tocochromanols, carotenoids, and squalene (Rudzińska et al., 2016).

The oil from the kernels could be extracted by conventional methods such as screw pressing, solvent extraction or pre-pressing followed by solvent extraction. Developing the "green chemistry" concept, these conventional methods tend to be replaced with different novel extraction techniques such as microwave, ultrasonic, high pressure-assisted extraction, supercritical fluid extraction (SFE), etc. Supercritical fluid extraction is an extraction te- 
chnique which could enhance the yield of target compounds, it is easier for manipulation, shortens extraction time, and decreases solvent/energy consumption and boost productivity. The most useful solvent for this extraction is $\mathrm{CO}_{2}$ with plenty of advantages such as low critical temperature $\left(31^{\circ} \mathrm{C}\right)$, non-toxicity, non-explosive nature and low price (Aladić et al., 2016)

After oil extraction from plum seed, a great amount of oil cakes with high protein content remains. These cakes could be a cheap protein source, useful to palliate protein world deficiencies, especially in developing countries. Plum oil cake (POC) has protein content of about 32-39\%. Also, the major essential amino acids in protein isolate from POC were arginine (21.7-30.5 mmol/100 g meal) and leucine $(16.2-21.6 \mathrm{mmol} / 100 \mathrm{~g}$ meal), and the predominant nonessential amino acid was glutamic acid (49.9-68.0 mmol/100 g meal) (Kamel et al. 1992). The limitation of using $\mathrm{POC}$ for human consumption is the presence of amygdalin. Amygdalin, cyanogenic glycoside, is non-toxic but in the presence of enzymes, it is hydrolysed and produces a benzaldehyde (hydrogen cyanide) (Garcia et al. 2016).

Recently, plum protein isolate (PI) has been receiving more and more attention as an ingredient that could be incorporated into food, cosmetic and pharmaceutical products. This protein isolate, besides a good functional property (solubility, water and oil adsorption capacity, foaming and emulsifying ability), has a potential for the production of bioactive peptides which can be released by in vitro enzymatic hydrolysis, gastrointestinal digestion by commercial enzymes (pepsin and pancreatin) and fermentation from the inactive parent proteins. Bioactive peptides from different plant sources can present diverse activities such as antithrombotic (Sabbione et al., 2015), cholesterol-lowering (Turpeinen et al., 2009), antimicrobial (Sedaghati et al., 2016), antioxidative (Sudhakar and Nazeer, 2015) and ACE inhibitory/antihypertensive (García-Tejedor et al., 2014) activities.

The aim of this study was to evaluate the potential of plum oil cakes, obtained after two different methods of oil extraction, to produce protein isolates as a source of bioactive peptides. The protein isolates have been compared and characterized by the solubility and electrophoresis profile. In vitro two steps hydrolysis process, with commercial digestive enzymes (pepsin and pancreatin), has been performed for determination of digestibility of plum protein isolate. The obtained digests were analysed for different biological activities, such as antioxidant and ACE inhibitory activity. Therefore, the present study would give new approach for valorisation of by-product of oil industry as a nutraceutical protein source.

\section{MATERIALS AND METHODS}

\section{Materials}

The plum kernels were obtained from the Association of Fruit Brandy Producers (Kneževi vinogradi, Croatia). Oil cakes were obtained by cold pressed (CP) and supercritical $\mathrm{CO}_{2}$ oil extraction (SFE).

\section{Protein extraction}

Protein isolate $(\mathrm{PI})$ from oil cakes obtained by cold pressing (PICP) and supercritical fluid extraction (PISFE) was extracted by alkali extraction with isoelectric precipitation. Plum cakes, defatted with n-hexane in ration 1:5, were suspended in water solution at alkali $\mathrm{pH} 10$ in ratio 1:10 that was set with $1 \mathrm{M} \mathrm{NaOH}$. After $30 \mathrm{~min}$ of extraction the slurry was extracted and filtered to remove the insoluble material. The dissolved proteins were precipitated by setting $\mathrm{pH}$ to 5 with $1 \mathrm{M} \mathrm{HCl}$. After centrifugation (Sorvall $\circledast$ RC-5B Refrigerated Superpeed Centrifuge, Du Pont Instruments, Newtown, PA, USA) at $10.000 \mathrm{rpm}$ and $4{ }^{\circ} \mathrm{C}$ for $20 \mathrm{~min}$, the precipitate was dried at $30^{\circ} \mathrm{C}$ for 24 hours. The dried precipitate was ground to obtain PI powder. The yield of PI was $1.7 \mathrm{~g} / 10 \mathrm{~g}$ oil cake.

\section{Protein solubility}

The solubility of PI was determined at $\mathrm{pH}$ range 2 to 9 and ionic strength range 0.1 $1 \mathrm{M} \mathrm{NaCl}$. Briefly, $10 \mathrm{mg}$ of $\mathrm{PI}$ was weighted into Eppendorf tubes and added to $1 \mathrm{~mL}$ of a buffer solution. Samples were constantly stirred for $1 \mathrm{~h}$ at $25^{\circ} \mathrm{C}$, using a 
Thermo Shaker TS- 100C (Bio-San, Latvia). After mixing the solutions were centrifuged at $14.500 \mathrm{rpm}$ for 10 min (Eppendorf Mini-spin plus, Eppendorf AG., Hamburg, Germany). Proteins from supernatant were determined by the Lowry et al. (1951) method.

\section{Determination of amygdalin}

Method was made according to Bolarinwaa et al. (2014), with some corrections. Briefly, protein cakes and PI were measured into a round-bottom flask $(100 \mathrm{~mL})$, and then added ethanol and the mixture was boiled under reflux during $120 \mathrm{~min}$. In the end of extraction, the extracts were filtered and evaporated under vacuum to remove ethanol. On this way prepared samples were analysed by HPLC (Agilent 1290 Infinity I HPLC system with an Agilent DAD detector). The column for separation was used a Supelco Analitycal HS-C18 column $(4.6 \times 250 \mathrm{~mm}, 5 \mu \mathrm{m})$ Sigma-Aldrich. The chromatographic conditions were: flow rate $1 \mathrm{~mL} / \mathrm{min}$, temperature $20{ }^{\circ} \mathrm{C}$, injection volume $20 \mu \mathrm{L}$ and UV detection at $210 \mathrm{~nm}$. Mobil phase consisted of distillation water: methanol $(75: 25 \mathrm{v} / \mathrm{v})$.

\section{Protein digestion}

PIs were hydrolysed using gastrointestinal proteases in order to simulate the human gastrointestinal environment. Digestion was performed using a combination of two enzymes, pepsin (E/S 1/25) and pancreatin (E/S 1/50), at $37^{\circ} \mathrm{C}$ during $4 \mathrm{~h}$. Protein suspension in water $(2.5 \mathrm{~g} / 100$ $\mathrm{cm}^{3}$ ) was pre-incubated at $37^{\circ} \mathrm{C}$, then adjusted to $\mathrm{pH} 2.5$ and added pepsin. After 120 min of gastric digestion, $\mathrm{pH}$ of the solution was adjusted to $\mathrm{pH} 7$ and added pancreatin and intestinal digestion was carried out next 120 min. The reaction mixture was heated at $100{ }^{\circ} \mathrm{C}$ for $5 \mathrm{~min}$ to stop reaction and centrifuged using $\mathrm{Ep}$ pendorf Mini spin plus (Eppendorf AG., Hamburg, Germany) at $14.500 \mathrm{rpm}$ for $10 \mathrm{~min}$ at room temperature. The collected supernatants were further analysed.

\section{Degree of hydrolysis}

The degree of the hydrolysis $(\mathrm{DH})$ was determined by method described by Popović et al. (2013).

\section{SDS-PAGE electrophoresis}

Proteins and digests were separated using sodium dodecyl sulphate polyacrylamide gel electrophoresis (SDS-PAGE), described by the method of Laemmli (1970).

\section{Determination of antioxidant activity}

Antioxidant activity of all samples were carried out by DPPH, ABTS radical scavenging and reducing power method, the methods was described by Čakarević et al. (2019).

\section{Assay of ACE-inhibitory activity}

The ACE- inhibitory activity of the hydrolysates was measured following the method described by Yoshi-Stark et al. (2004).

\section{Statistical analysis}

The data were in triplicate, and subjected to statistical analysis, using analysis of variance (ANOVA) to determine significant differences between the samples ( $p<$ 0.05). Differences between the treatment means were separated using Duncan's multiple range tests.

\section{RESULTS AND DISCUSSION}

The proximate compositions of the plum oil cakes and protein isolates obtained from them are shown in Table 1. Protein was the major component of both plum cakes, with $50.69 \%$ for CP and $48.94 \%$ for SFE. Carbohydrates and fibres were the followed components in both cakes. Both Pls obtained from plum oil cakes by isoelectric precipitation, have protein content $97.94 \%$ for PICP and $99.15 \%$ for PISFE. Generally, utilization of this byproduct for protein and oil production could be limited by the presence of cyanogenic glycosides such as amygdalin therefore we determined its content. Toxicity of amygdalin comes from benzaldehyde, with a typical bitter taste, and cyanide, as a result of the hydrolysis of amygdalin. According to the European Food Safety Authority (EFSA) it was set a maximum level of cyanide of $50 \mathrm{mg} / \mathrm{kg}$ in nougat, marzipan or their substitutes or similar products, 5 $\mathrm{mg} / \mathrm{kg}$ in canned stoned fruits, and 35 $\mathrm{mg} / \mathrm{kg}$ in alcoholic beverages (EFSA, 2016). 
Table 1.

Chemical composition of plum oil cakes (POC) and protein isolates (PI) obtained from oil extraction by cold pressing (CP) and supercritical fluid extraction (SFE)

\begin{tabular}{clcc}
\hline Composition & CP & SFE \\
\hline \multirow{4}{*}{ Moisture (\%) } & $10.80 \pm 0.145^{\mathrm{b}}$ & $6.27 \pm 0.315^{\mathrm{a}}$ \\
& Crude fibre (\%) & $5.86 \pm 0.315^{\mathrm{a}}$ & $11.57 \pm 0.345^{\mathrm{b}}$ \\
& Crude lipids (\%) & $10.09 \pm 0.165^{\mathrm{a}}$ & $10.63 \pm 0.12^{\mathrm{b}}$ \\
& Total carbohydrate (\%) & $12.77 \pm 0.015^{\mathrm{b}}$ & $12.59 \pm 0.05^{\mathrm{a}}$ \\
& Reducing sugars (\%) & $10.40 \pm 0.025^{\mathrm{a}}$ & $10.90 \pm 0.025^{\mathrm{b}}$ \\
& Crude protein (\%) & $50.69 \pm 0.53^{\mathrm{b}}$ & $48.93 \pm 0.625^{\mathrm{a}}$ \\
\hline \multirow{2}{*}{ PI } & Protein content (\%) & $97.94 \pm 0.875^{\mathrm{a}}$ & $99.15 \pm 0.095^{\mathrm{a}}$ \\
& Amygdalin content (mg/g PI) & $0.027 \pm 0.00^{\mathrm{b}}$ & $0.020 \pm 0.001^{\mathrm{a}}$
\end{tabular}

Values represent average of triplicates $\pm S D$. Different superscript letters (a and b) indicate significant difference $(p<0.05)$ within the same row

a)

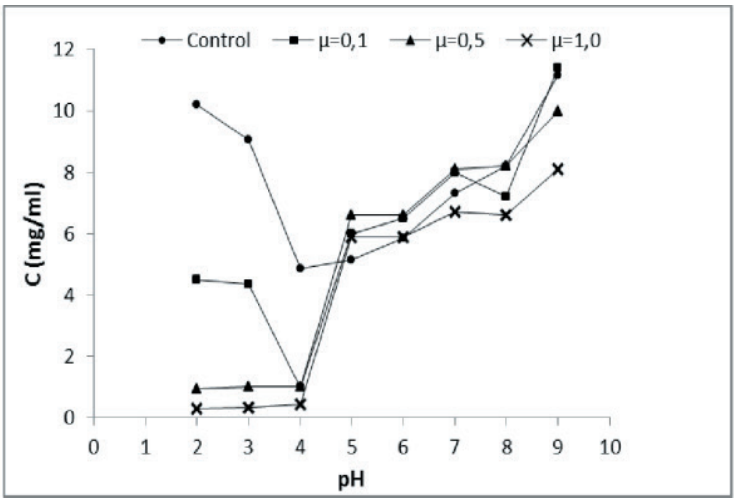

b)

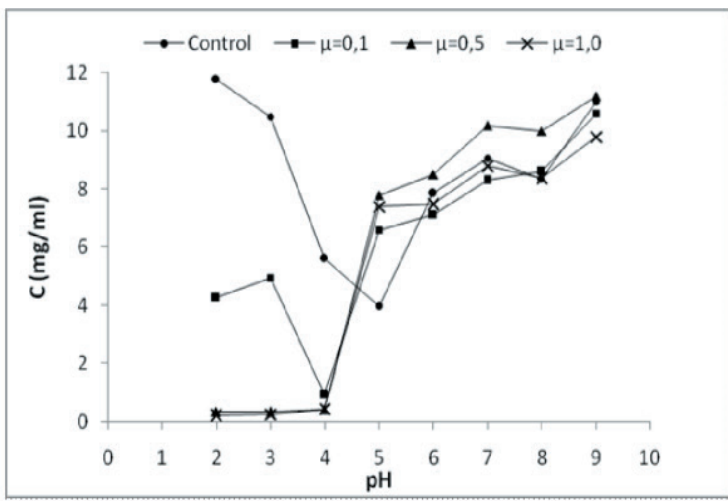

Figure 1. Influence of $\mathrm{pH}$ and ionic strength $(\mu)$ on protein solubility of plum oil cake protein isolates obtained by a) cold pressing (PICP) and b) supercritical fluid extraction (PISFE)

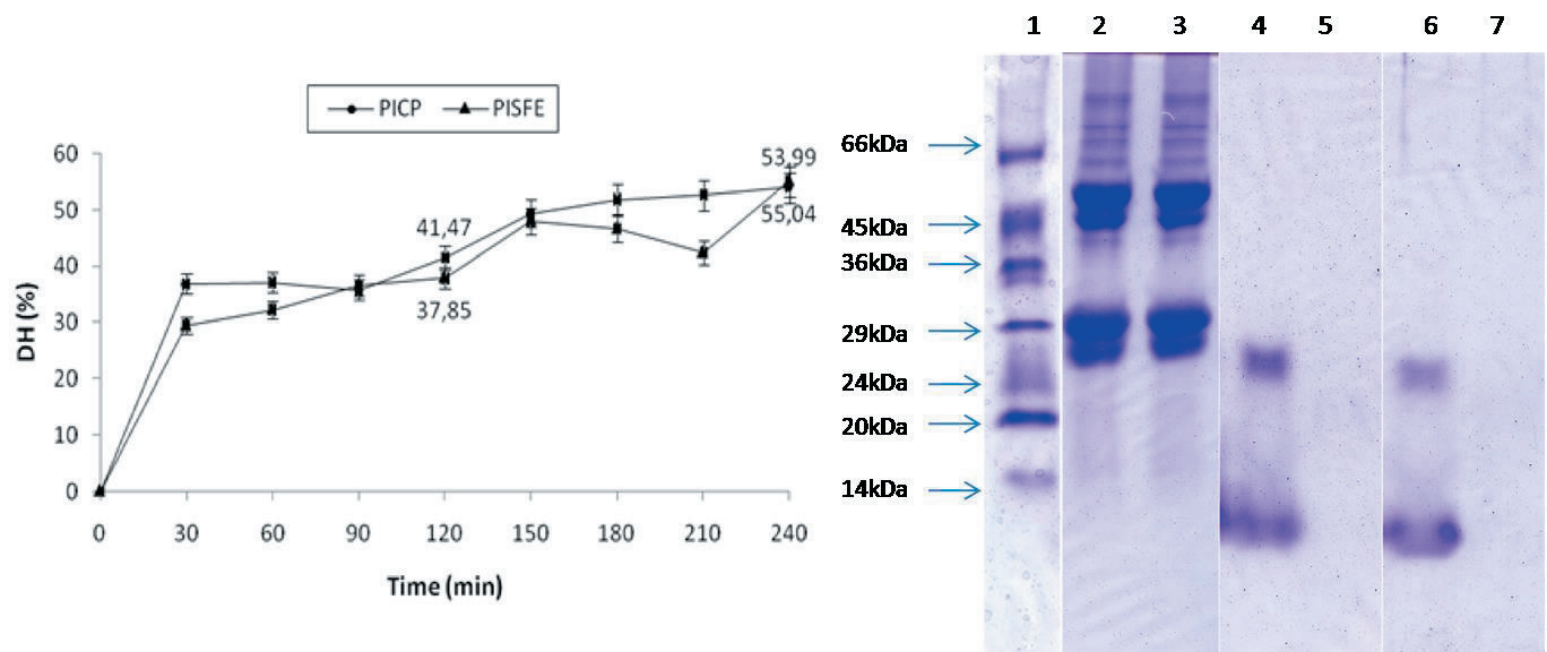

Figure 2. (a) Degree of hydrolysis $(\mathrm{DH})$ of plum oil cake protein isolates obtained by cold pressing (PICP) and supercritical fluid extraction (PISFE) during in vitro digestion (b) SDS-PAGE analysis of plum oil cake protein isolates and their digests: (1) molecular mass markers SDS 7, (2) PICP, (3) PISFE, (4) PICP pepsin, (5) PICP pancreatin, (6) PISFE pepsin, (7) PISFE pancreatin

Similarly, our previous reports (Čakarević et al. 2019) and literature data (Garcia et al. 2016) showed that protein isolates from apricot cakes either did not contain amyg- 
dalin or had a low amount of amygdalin. The fatal dose of $\mathrm{HCN}$ has been reported as $0.5 \mathrm{mg} / \mathrm{g}$. The obtained results showed that amygdalin content in Pls is in amount considered as safe (Table 1).

\section{Protein solubility}

The protein solubility profiles of $\mathrm{PI}$ from both sources $\mathrm{CP}$ and SFE at different $\mathrm{pH}$ levels and ionic strengths are shown in Fig. $1(a, b)$, where it could be seen that the protein solubility patterns were similar for both samples. The lowest solubility for both Pls was observed at $\mathrm{pH} 4(3.95$ $\mathrm{mg} / \mathrm{mL}$ for SFE and $4.85 \mathrm{mg} / \mathrm{mL}$ for CP), and the higher solubility was evident under extremely acidic $(\mathrm{pH} 2)$ and alkaline $(\mathrm{pH} 9)$ conditions. This result indicates the isoelectric point of the extracted $\mathrm{PI}$ was at $\mathrm{pH}$ 4 , which is in correlation with general trend that most of food proteins are acidic, with isoelectric point at $\mathrm{pH} 4-5$ (Roodsamran and Sothornvit 2018; Chambal et al. 2013; Wu et al. 2009). Significant influence of ionic strength was observed mostly at the extreme acidic $\mathrm{pH}$, manifested as the salting-out effect, with decreasing solubility of $\mathrm{PI}$. Over $\mathrm{pH}$ range from $\mathrm{pH} 4$ to $\mathrm{pH} 8$ salting-in effect occurred with a minor increase in solubility. Similar trend was observed from our previous reports for $\mathrm{PI}$ from apricot kernel cake after CP and SFE oil extraction (Čakarević et al. 2019).

\section{Digestibility of protein isolate}

Digestibility of PIs was subjected to evaluate the capacity to release peptides which could have potential bioactive effects when PIs were directly consumed. In order to simulate digestion of human gastrointestinal tract, proteases, pepsin and pancreatin were used and process of digestion was monitored by measuring $\mathrm{DH}$. The hydrolysis curves of Pls after digestion are shown in Figure 2a. During pepsin digestion the $\mathrm{DH}$ of PICP and PISFE reached $41.47 \pm 0.79 \%$ and $37.85 \pm 0.73 \%$, respectively. Moreover, subsequent digestion by pancreatin led to an increase of $\mathrm{DH}$ in both $\mathrm{PI}$ digests, reaching similar $\mathrm{DH}$ values $(53.99 \pm 0.60 \%$ for PICP and $55.04 \pm 1.00 \%$ for PISFE, respectively). The electrophoretic profiles of Pls and their products of in vitro digestion by pepsin and subsequently by pan- creatin are shown in Fig. 2b. Electrophoresis of Pls exhibited the presence of two groups of intense bands, corresponding to polypeptide complexes with molecular weight between $36-45 \mathrm{kDa}$ and 20-29 kDa (lines 2 and 3). Similar protein patterns were previously reported for other seeds of genus Prunus L. (Garcia et al., 2015). In the digests, both Pls were further degraded to apparent molecular weights lower than $20 \mathrm{kDa}$. After pepsin, digests of both Pls showed lower molecular weight fragments notably bellow 20 and $14 \mathrm{kDa}$ (lines 4 and 6). During the second enzymatic step, after treatment by pancreatin, no visible bands were obtained in the gel (lines 5 and 7). These results showed that Pls are not resistant to digestive proteases. Similar results were reported for other digests of plant proteins obtained from almond (Sze-Tao and Sathe, 2000) and oil palm kernel (Tapal et al., 2016)

\section{Antioxidant capacity of digested PIs}

Antioxidant capacities of protein digests obtained from Pls after both in vitro digestion steps were studied by DPPH and ABTS scavenging assays as well as by reducing power assay (Figure $3 \mathrm{a}, \mathrm{b}$ ). In general, all digests showed radical scavenging capacity. Values of antioxidant activity depended on the chosen assay (Figure 3). The DPPH radical scavenging activity of PICP and PISFE digests after pepsin digestion was $12.33 \%$ and $24.43 \%$, respectively. Pancreatin digestion of PICP and PISFE digests led to an increase of the scavenging activity to $30.33 \%$ and $23.38 \%$, respectively. Similar trend was obtained with ABTS radical scavenging activity of PIs, with $24.96 \%$ to $27.82 \%$ after pepsin digestion and $31.81 \%$ to $36.67 \%$ following pancreatin digestion. Reducing ability of digests indicated their capacity to donate electrons and it increased with increasing $\mathrm{DH}$ values. The digests from both Pls after pepsin digestion showed significant increase in the reducing power, with continued increase during pancreatin digestion. Results proved that Pls were cleaved into small peptides and free amino acids by digestive proteases which are reported to exert greater antioxidant activity than their parent proteins or large polypeptides (Vaštag et al., 2013). 


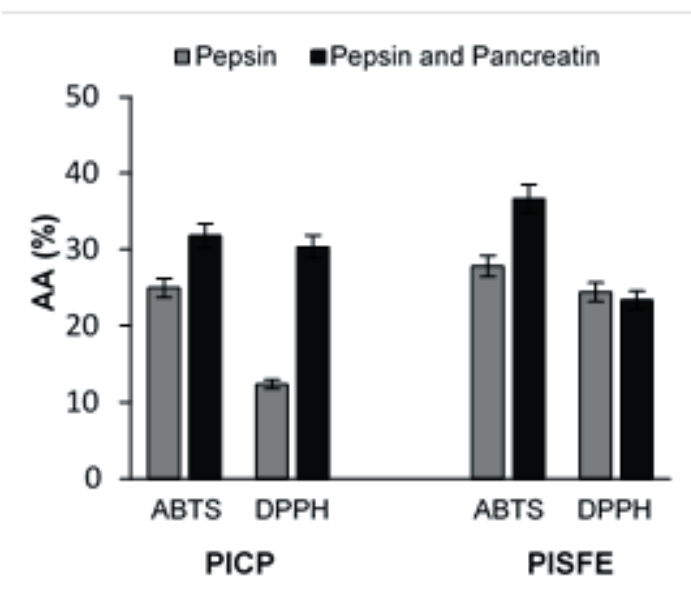

a)

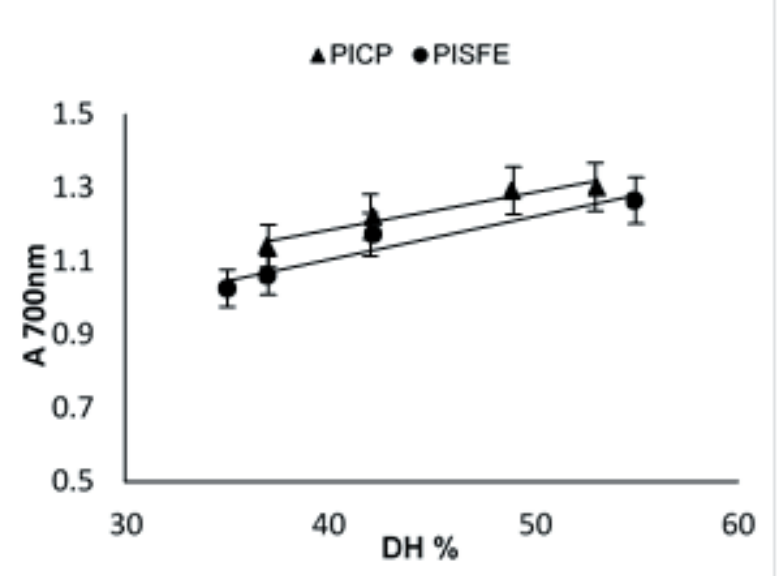

b)

Figure 3. (a) Antioxidant activities (AA) of hydrolysates obtained after in vitro digestion of plum oil cake protein isolates derived by cold pressing (PICP) and supercritical fluid extraction (PISFE) measured as ABTS and DPPH radical scavenging activity (b) Reducing power of hydrolysates obtained after in vitro digestion of plum oil cake protein isolates derived by cold pressing $(\mathrm{CP})$ and supercritical fluid extraction (SFE) with different degrees of hydrolyses (DH)

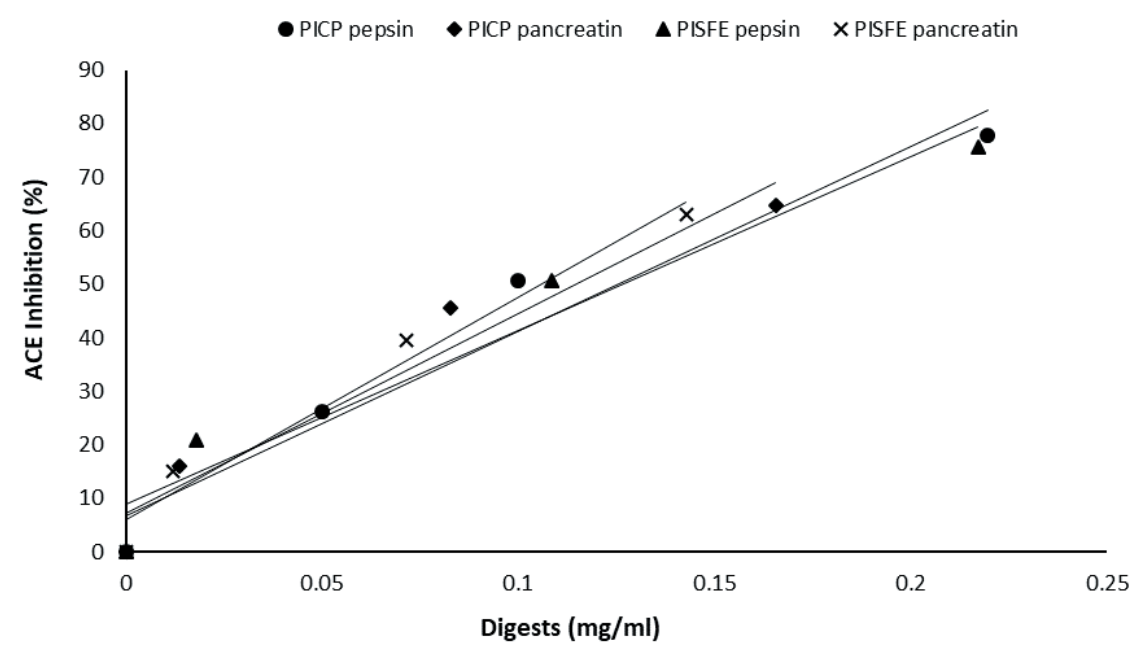

Figure 4. ACE inhibition capacity in function of different concentrations of plum oil cake protein digests

\section{ACE inhibitory capacity of digests}

Both Pls and associated digests were screened for their ACE inhibitory potential. Native PIs did not show ACE inhibitory activity (data not shown), but their digests exerted a significant inhibitory activity, indicating the release of ACE inhibitory peptides during in vitro digestion (treated by pepsin and pancreatin). Figure 4 shows the linear function of ACE inhibition activity and sample concentrations. When the obtained ACE inhibitory activities of digests were presented as $I C_{50}$, then values for $\mathrm{PICP}$ were at $0.125 \mathrm{mg} / \mathrm{mL}$ and at 0.127 $\mathrm{mg} / \mathrm{mL}$ for PISFE. Moreover, the inhibitory activity increased following treatment with pancreatin, with $\mathrm{IC}_{50}$ values at 0.115 $\mathrm{mg} / \mathrm{mL}$ for PICP and at $0.106 \mathrm{mg} / \mathrm{mL}$ for PISFE. Similar results have been reported for antihypertensive peptides obtained from protein isolates after simulated gastrointestinal digestion, from sunflower (Megias et al., 2004), apricot seed (Čakarević et al., 2019), and chia protein (Pablo Osorio et al., 2019).

\section{CONCLUSIONS}

Plum oil cake which remains after oil extraction process could be an alternative 
source of bioactive compounds which have different biological activities that could provide health benefits. This residue is an unused protein source with protein content of about $50 \%$ hence the protein exploitation from this source is a good way to increase the value of this agricultural by-product. Protein isolate extracted from defatted plum seed flour by alkali solution along with isoelectric precipitation contained about $90 \%$ of protein. Bioactive peptides, released from parent proteins during enzymatic hydrolysis, exhibited diverse bioactivities, such as antioxidant and blood pressure-lowering (ACE inhibitory) effect. Presented results indicated that plum kernel proteins could be used as a functional food additive, which could, following digestion, be the source of peptides that exert positive effects on human health.

\section{ACKNOWLEDGEMENTS}

This work was supported in part by the Croatian Science Foundation under the project "Application of innovative techniques of the extraction of bioactive components from by-products of plant origin" (UIP-2017-05-9909); grant number III 46010 from Ministry of Education, Science and Technological Development of Republic of Serbia and as part of the "Atrium of Knowledge" project co-financed by the European Union from the European $\mathrm{Re}$ gional Development Fund and the Operational Programme Competitiveness and Cohesion 2014-2020.

\section{REFERENCES}

1. Aladić, K., Vidović, S., Vladić, J., Balić, D., Jukić, H., Jokić, S. (2016). Effect of supercritical $\mathrm{CO}_{2}$ extraction process parameters on oil yield and pigment content from by-product hemp cake. International Journal of Food Science and Technology, 51, 885-893.

2. Bolarinwa, F.I., Orfilaa, C., Morgana, M.R.A. (2014). Amygdalin content of seeds, kernels and food products commercially-available in the UK. Food Chemistry, 152, 133-139.

3. Čakarević J., Vidović S., Vladić J., Gavarić A., Jokić S., Pavlović N., Blažić M., Popović J. (2019). Production of bio-functional protein through revalorization of apricot kernel cake. Foods, 8.

4. Chambal B., Bergenståhl B., Dejmek P. (2012). Edible proteins from coconut milk press cake; one step alkaline extraction and charac- terization by electrophoresis and mass spectrometry. Food Research International, 47, 146151.

5. (EFSA) EFSA Panel on Contaminants in the Food Chain (2016). Acute health risks related to the presence of cyanogenic glycosides in raw apricot kernels and products derived from raw apricot kernels. EFSA Journal, 14 (4), 4424.

6. Garcia, M.C., Endermann, J., González-Garcia, E., Marina, M.L. (2015). HPLC-Q-TOF-MS Identification of antioxidant and antihypertensive peptides recovered from cherry (Prunus cerasus L.) subproducts. Journal of Agricultural and Food Chemistry, 63, 1514-1520.

7. Garcia, M.C., González-Garcia, E., VásquezVillanueva, R., Marina, M.L. (2016). Apricot and other seed stones: Amygdalin content and the potential to obtain antioxidant, angiotensin I converting enzyme inhibitor and hypocholesterolemic peptides. Food and Function, 7, 4693-4701.

8. Garcia-Tejedor, A., Sánchez-Rivera, L., Castelló-Ruiz, M., Recio, I., Salom, J. B., Manzanares, P. (2014). Novel antihypertensive lactofferin-derived peptides produced by Kluyveromyces marxianus: gastrointestinal stability profile and in vivo Angiotensin I-Converting Enzyme (ACE) inhibition. Journal of Agricultural and Food Chemistry, 52, 1609-1616.

9. Kamel B.S., Kakuda Y. (1992). Characterization of the seed oil and meal from apricot, cherry, nectarine, peach and plum. Journal of the American Oil Chemists' Society, 69, 492-494.

10. Laemmli, U.K. (1970). Cleavage of structural proteins during the assembly of head of bacteriophage T4. Nature, 227, 680-685.

11. Lowry, O.H., Rosenbrough, N.J., Fair, A.L., Randall, R.J. (1951). Protein measurement with the Folin-phenol reagents. Journal of Biological Chemistry, 193, 265-275.

12. Megias, C., Mar Yust, M., Pedroche, J., Lquari, H., Giron-Calle, J., Alaiz, M., Millan, F., Vioque J. (2004). Purification of an ACE inhibitory peptide after hydrolysis of sunflower (Helianthus annuus L.) protein isolates. Journal of Agricultural and Food Chemistry, 52, 19281932.

13. Pablo-Osorio, B.S., Mojica, L., Urias-Silvas, J. E. (2019). Chia seed (Salvia hispanica L.) pepsin hydrolysates inhibit angiotensin-converting enzyme by interacting with its catalytic site. Journal of Food Science, 84, 1170-1179.

14. Popović, Lj., Peričin, D., Vaštag, Ž., Popović, S., Krimer, V., Torbica, A. (2013). Antioxidative and functional properties of pumpkin oil cake globulin hydrolysates. Journal of the American Oil Chemist's Society, 90, 1157-1165.

15. Rodsamran, P., Sothornvit R. (2018). Physicochemical and functional properties of protein concentrate from by-product of coconut processing. Food Chemistry, 241, 364-371.

16. Rudzińska, M., Górnaś, P., Rackyz, P., Soliven, A. (2016). Sterols and squalene in apricot (Prunus armeniaca L.) kernel oils: the variety as a 
key factor. Natural Product Research, 31, 8488.

17. Sabbione, A.C., Scilingo, A., Añón, M.C. (2015). Potential antithrombotic activity detected in amaranth proteins and its hydrolysates. LWT- Food Science and Technology, 60, 171177.

18. Sedaghati, M., Ezzatpanah, H., Boojar, M.M. A., Ebrahimi, M.T., Kobarfard, F. (2016). Isolation and identification of some antibacterial peptides in the plasmin-digest of $\beta$-casein. LWT- Food Science and Technology, 68, 217225.

19. Sudhakar, S., Nazeer, R.A., 2015. Structural characterization of an Indian squid antioxidant peptide and its protective effect againts cellular reactive oxygen species. Journal of Functional Food, 14, 502-512.

20. Sze-Tao, K.W.C., Sathe, S.K. (2000). Functional properties and in vitro digestibility of almond (Prunus dulcis L.) protein isolate. Food Chemistry, 69, 153-160.

21. Tapal, A., Vegarud, G.E., Sreedhara, A., Hegde, P., Inamdar, S., Tiku, P.K. (2016). In vitro human gastro-intestinal enzyme digestibility of globulin isolate from oil palm (Elaeis guineensis var. tenera) kernel meal and the bioactivity of the digest. Royal Society of Chemistry, 6, 20219-20229.

22. Turpeinen, A.M., Kumpu, M., Rönnback, M., Seppo, L., Kautiainen, H., Jauhiainen, T., Vapaatalo, H., Korpela, R. (2009). Antihypertensive and cholesterol-lowering effects of a spread containing bioactive peptides IPP and VPP and plant sterols. Journal of Functional Food I, 260-265.

23. Vaštag, Ž., Popović, Lj., Popović, S., PeričinStarčević, I., Krimer-Malešević, V. (2013). In vitro study on digestion of pumpkin oil cake protein hydrolysate: Evaluation of impact on bioactive properties. International Journal of Food Science and Nutrition, 64, 452-460.

24. Wu H., Wang Q., Ma T., Ren J. (2009). Comparative studies on the functional properties of various protein concentrate preparations of peanut protein. Food Research International, 42, 343-348.

25. Yoshie-Stark, Y., Bez, J., Wada, Y., Wäsche, A. (2004). Functional properties, lipoxygenase activity, and health aspects of Lupinus albus protein isolates. Journal of Agricultural and Food Chemistry, 52, 7681-7689.

\title{
ПРОТЕИНСКИ ИЗОЛАТ УЉАНЕ ПОГАЧЕ СЕМЕНА ШЉИВЕ: ПОТЕНЦИЈАЛНИ ИЗВОР БИОАКТИВНИХ ПЕПТИДА
}

\author{
Јелена Ц. Чакаревић ${ }^{1}$, Сенка С. Видовић ${ }^{1}$, Јелена 3. Владић ${ }^{1}$, Стела Д. Јокић ${ }^{2}$, Ника С.
} Павловић ${ }^{3}$, Љиљана М. Поповић ${ }^{*}$

${ }^{1}$ Универзитет у Новом Саду, Технолошки фракултет, 21000 Нови Сад, Булевар цара Лазара бр.

\author{
1, Србија
}

${ }^{2}$ Свеучилиште Јосипа Јурја Штросмајера, Прехрамбено-технолошки фракултет, 31000 Осијек, Трг Светог Тројства 3, Хрватска

${ }^{3}$ Свеучилиште Јосипа Јурја Штросмајера, Медицински факултет, 31000 Осијек, Цара Хадријана 10E, Хрватска

Сажетак: У овој студији описане су и упоређене функционалне особине и сварљивост протеинских изолата добијених из уљаних погача шљиве поступцима суперкритичне екстракције уља и хладним пресовањем. Садржај амигдалина у протеинским изолатима се налазио у количини мањој од прописане. Растворљивост оба протеинска изолата одговара профилима растворљивости биљних протеина. Протеински изолати су показали добру сварљивост, што је доказано применом гастроинтестиналних протеаза (пепсин и панкреатин) у процесу in vitro дигестије. За карактеризацију сварљивости протеина коришћена је SDS-PAGE анализа, којом је доказана потпуна сварљивост протеинских изолата. Помоћу три комплементарне методе одређена је антиоксидативна активност добијених хидролизата, као и инхибиторно дејство на ангиотензин-І конвертујући ензим (ACE) који директно утиче на појаву хипертензије. Сви добијени протеински хидролизати деловали су као хватачи слободних радикала и инхибитори ACE. Стога се показало да су протеински изолати добијени из уљане погаче шљиве потенцијални извор функционалних додатака са добром сварљивошћу и биоактивним својствима.

Кључне речи: протеини уљане погаче, суперкритична екстракција, ин витро дигестија, АCE инхибитори, антиоксидативна активност

Received: 18 November 2019

Received in revised form: 5 December 2019

Accepted: 11 December 2019 